\title{
Amplitude of malondialdehyde level in tissues of rats during Escherichia coli infection in the hypobiosis state
}

\author{
I. Tekdemir, V. Tsvilikhovskyi \\ National University of Life and Environmental Sciences of Ukraine, Kyiv \\ Corresponding author. Email: ilonatekdemir@gmail.com
}

Paper received 03.02.20; Accepted for publication 19.02.20.

\section{https://doi.org/10.31174/SEND-NT2020-224VIII27-06}

\begin{abstract}
The article addresses the level of malondialdehyde in the blood plasma and liver tissues of rats during $E$. coli infection at the initial stage of the disease, the stage of progressive symptomatology and at the stage of the total exhaustion. It was determined that the level of MDA in the tissues of animals was increased gradually with the subsequent stage of the disease. It was established that the introduction of rats with $E$. coli infection at any stage into a state of artificial hypobiosis had a pronounced positive effect, since the MDA level decreased significantly, which was characterized by a tendency to return to the level of control values after withdrawing the animals from the state of artificial hypobiosis.
\end{abstract}

Keywords: hypobiosis, MDA, liver tissue, blood, stages of E. coli disease.

Introduction. The studies into the molecular bases of hypobiosis - a state of artificial sleep, the application of which is both promising and relevant in all areas of medical practice (anesthesiology, resuscitation, surgery), engage the whole work groups of scientists. It has been found out that in the state of hypobiosis no radiological symptoms occur, and radiation resistance of the animal organism is increased during the artificial infection with microorganisms [1, 2]. Thus, the use of artificial hypobiosis in the state of infectious diseases may be considered to be a promising alternative to antibiotics. As the early results show that the body is not susceptible to infection in the state of hypobiosis, it is only logical to question whether hypobiosis may be used instead of complex antibiotic therapy and sanitary-epidemiological measures in the treatment of infectious diseases. In particular, those with rapid development are often diagnosed and pose danger to different age groups in comparison to other infectious diseases. Given at least a slight likelihood in the application of hypobiosis beneficial to human changes in the course of infection, such as escherichiosis, it is crucial to apply this knowledge for the infectious therapy of the future. With that in mind, studying the level of malondialdehyde, as a marker of oxidative processes in the body, will make it possible to predict under what circumstances the regime of hypobiosis will be the least traumatic and the most suitable for therapeutic purposes.

Brief overview of publications on the topic. The question of hypobiosis is far from new to medicine, the first observations of the state of artificial sleep date back to 1940s1950s [3, 4], but attempts to put this state into practice have found their urgency in our time, since there has accumulated a lot of information on biochemistry hypobiosis and principles of an organism existence in the states of hypercapnia, hypoxia and hypothermia [2, 5, 6, 7]. Given the above, scientists have come to focus on the practice of hypobiosis as such, which will make it possible to replace or supplement anesthesia, and enhance the surgical practice [6].

We have also suggested that hypobiosis can be used as an agent to counteract the infection of bacterial origin - escherichiosis. Escherichiosis is a disease that is often diagnosed both in in-patients and out-patients of medical institutions, and its symptoms are well known: reduced appetite, diarrhea, fever leading to exhaustion of the body, lethargy, paleness of the skin, etc. The frequency and amplitude of the symptoms' expression depend on the condition of the patient's body, age, and the strain of Escherichia coli Migula that caused the infection. The highest mortality is recorded among children and the elderly [8]. As a result of studies into the effect of hypobiosis on the time frames of survival of animals with escherichiosis, the application of the method was found to be highly successful in the early and late stages of the disease [9]. However, the question of biochemical changes in the body from the perspective of using hypobiosis as a therapeutic agent in the treatment of escherichiosis has not been investigated. Although it is known that a situation that goes beyond the environment typical for the body is stressful for the living organism, and is inevitably accompanied by an increase in tissues of the malondialdehyde level (MDA), the level and duration of which can relatively determine the degree of aggressive factor that triggered stress and the severity of this stress in the body, the ability of the body to withstand the phenomenon dangerous to it. MDA is a universal stress molecule in biology, and its excess formation is a symbol of oxidative damage, without any connection to the tissue specificity of the process. On the other hand, MDA molecules are always present at the so-called "background" level in the body, since MDA is an endogenous aldehyde, a product of metabolic transformations of polyunsaturated fatty acids [10]. The excessive MDA concentrations that are higher than physiological ones are able to activate the complement system, protein kinase $\mathrm{C}$, to induce autoimmune and inflammatory processes, DNA mutations, etc. [11]. Therefore, studying the level of MDA in different states of the body provides the basis for determining the stress-forming properties of exogenous influences and determining the response to body stress.

Since the states of hypobiosis for homoothermic animals is triggered by factors such as hypoxia, hypercapnia and hypothermia, which in themselves have a stressful effect for the body, but at the same time lead to an essential decrease in its reactivity, a significant slowdown of metabolic transformations, so as a consequence their complex action should be accompanied by reduced stress, obviously even in the case of a diseased body.

Purpose: To study the level of malondialdehyde in liver tissues and blood plasma of rats with escherichiosis at different stages of disease development by introducing them into the state of artificial hypobiosis.

Materials and methods. The experiments were performed on white outbred rats (weight $60 \pm 5 \mathrm{~g}, \mathrm{n}=120$ ), the 
keeping conditions were standard for vivarium. Experimental animals are in compliance with the requirements of the European Convention for the Protection of Vertebrate Animals Used for Experimental and Other Scientific Purposes, and the Law of Ukraine "On the Protection of Animals against Cruelty" No. 3447 of 21.02.2006.

The state of artificial hypobiosis was modeled by the Bakhmetev-Jaya-Anjus method (closed vessel model) [1, 3, 12], which provided for 3-hour cooling $\left(3-5^{\circ} \mathrm{C}\right)$ of animals in a hermetic chamber with a volume of $3 \mathrm{dm}^{3}$. The healthy animals and animals with escherichiosis at different stages of the disease were administered into the state of artificial hypobiosis. The simulation of the infectious-inflammatory process (escherichiosis) in experimental animals was performed using the enterotoxigenic strain of Escherichia coli O6: K - (ATCC 25922) [13]. Animals were infected orally (per os) with a dose of $3 \times 10^{8} \mathrm{CFU} / 50 \mathrm{~g}$ of the rat. Stage of the disease was defined as: stage I of escherichiosis - the stage of symptoms onset (occurred on the fourth day after infection), stage II - stage of progressive symptomatology of the disease (developed on the fifth day after infection), stage III - stage of total exhaustion of the organism (the sixth day after introducing the infection) [9].

Animals were divided into groups: controls or intact animals (euthanasia was performed under normometry conditions, chloroform was used as anesthesia); healthy animals in the state of hypobiosis (decapitation was performed 3 hours after the introduction into the state of hypobiosis, without removing from it, premedication in this and all subsequent groups was also performed with chloroform); healthy animals one day after removing from hypobiosis (euthanasia was performed 24 hours after the removal from hypobiosis); animals with escherichiosis at the stages I, II, III of the disease (euthanasia performed at the corresponding stages of the disease); animals with escherichiosis who were introduced at the stages I, II, III of the disease into a state of hypobiosis (euthanasia was performed 3 hours after the introduction into the state of hypobiosis, without removing it); animals with escherichiosis at the stage I, II, III whose state was evaluated 24 hours after the removal from hypobiosis (decapitated 24 hours after withdrawal from hypobiosis).

Liver tissue and blood plasma were selected for the research. The MDA level was determined by A. Kohn and V. Liversage method in the modification of Y. Vladimirov and A. Archakov, which is based on the ability of MDA (as one of the lipid peroxidation derivatives - LPO) in acidic medium at high temperature $\left(100^{\circ} \mathrm{C}\right)$ to interact with thiobarbituric acid with the formation of the trimethin complex of a reddish-pink color, with the composition of MDA: TBA 1:2, the maximum absorption of which takes place at $532 \mathrm{~nm}$ [14].

Statistical analysis was performed using Student's t-test, at that the mean arithmetic and standard error $(\mathrm{M} \pm \mathrm{m})$ were calculated, the significance of differences was stated at $\mathrm{P} \leq 0.05$.

Results and Discussion. As a result of the conducted research it is established that in the infected animals the processes of lipid peroxidation are activated, as evidenced by a meaningful increase in the level of MDA in the blood and tissues of the rat liver at the first stage of the disease - the stage of the onset of escherichiosis symptoms (Fig. 1).
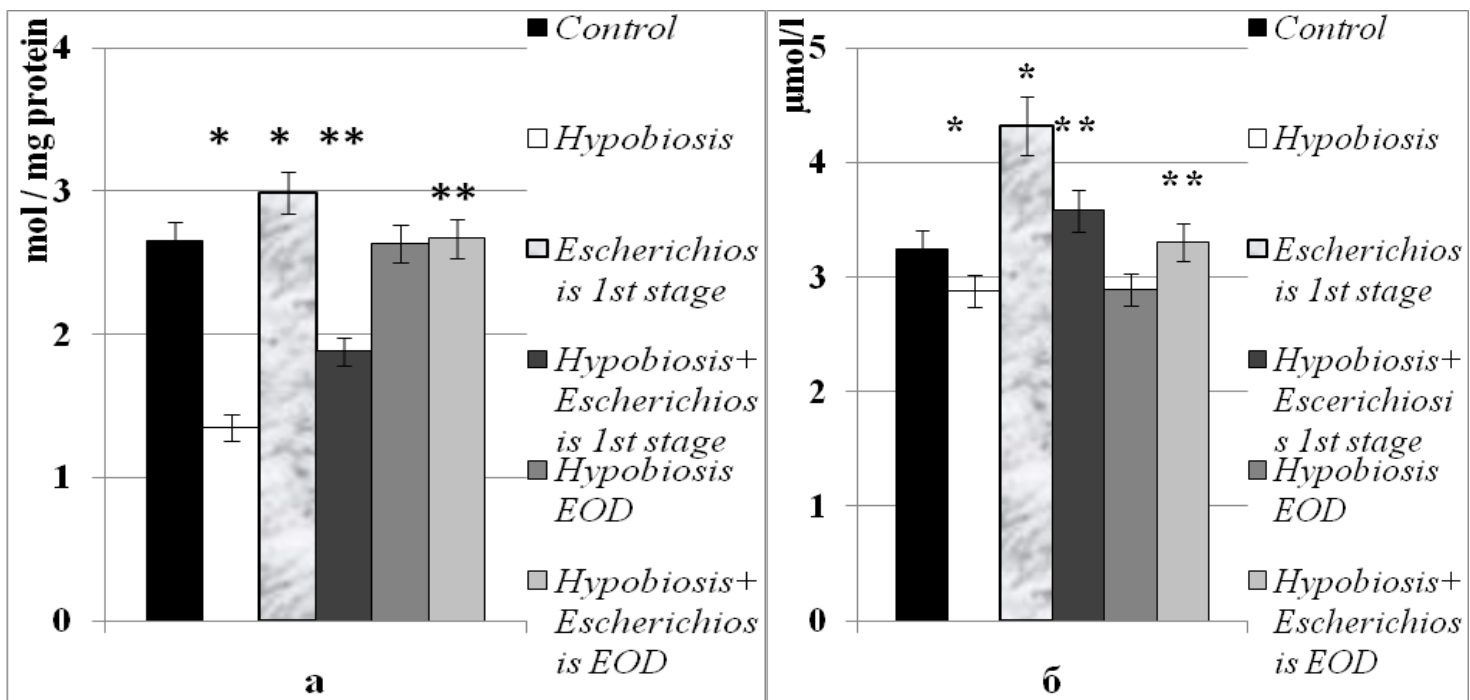

Fig. 1. The level of MDA in liver tissues (a) and blood plasma (b) of rats that were introduced into the state of hypobiosis at the first stage of escherychiosis - the stage of onset of disease symptoms

Note hereinafter: * - the difference is meaningful as compared to the MDA level of the control animals; ** - the difference is meaningful as compared to the MDA level of the diseased animals, $\mathrm{P} \geq 0.05$.

Notably, the more difficult stage of the disease development is accompanied by a more pronounced intensification of the processes of LPO, as evidenced by a gradual increase in the level of MDA in the blood (Fig. 2b), which at the stage of total exhaustion of the body from the disease exceeds twice the values of healthy animals (Fig. 3b).

It is known that E. coli strain ATCC 25922 is an enterotoxigenic strain whose main method of damage to the body is the production of enterotoxins and, as a consequence, hypersecretion of water and electrolytes by enterocytes, which leads to dehydration of the body, disturbance of watersalt balance [15]. Such changes are profoundly expressed in the last stages of the disease and induce a change in physiological and biochemical conditions in which the oxidativereductive reactions of the body, accompanied by oxidative stress and, as a consequence, the activation of LPO. The end product of metabolic fatty acid metabolism is reactive malonic dialdehyde, which we have detected in the blood plasma and liver tissues of the diseased animals. 
The changes in MDA concentration at the initial stage of the disease (stage I) are much more pronounced in the blood plasma than in the liver tissues of diseased animals (Fig. 1a, b), therefore, it is in the blood that the symptoms of oxidative stress in the conditions of escherichiosis can be recorded first.
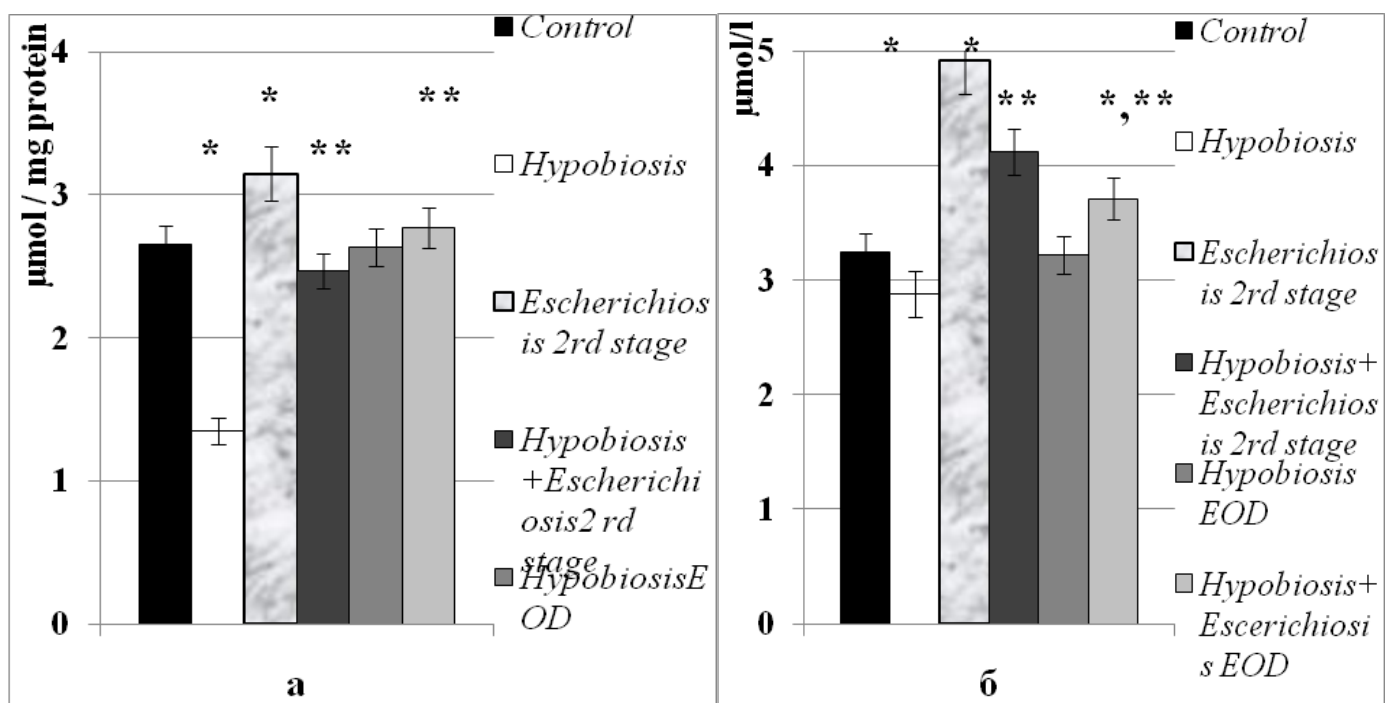

Fig. 2. The level of MDA in liver tissues (a) and blood plasma (b) of rats that were introduced into the state of hypobiosis at the second stage of escherichiosis - a stage of progressive symptomatology of the disease
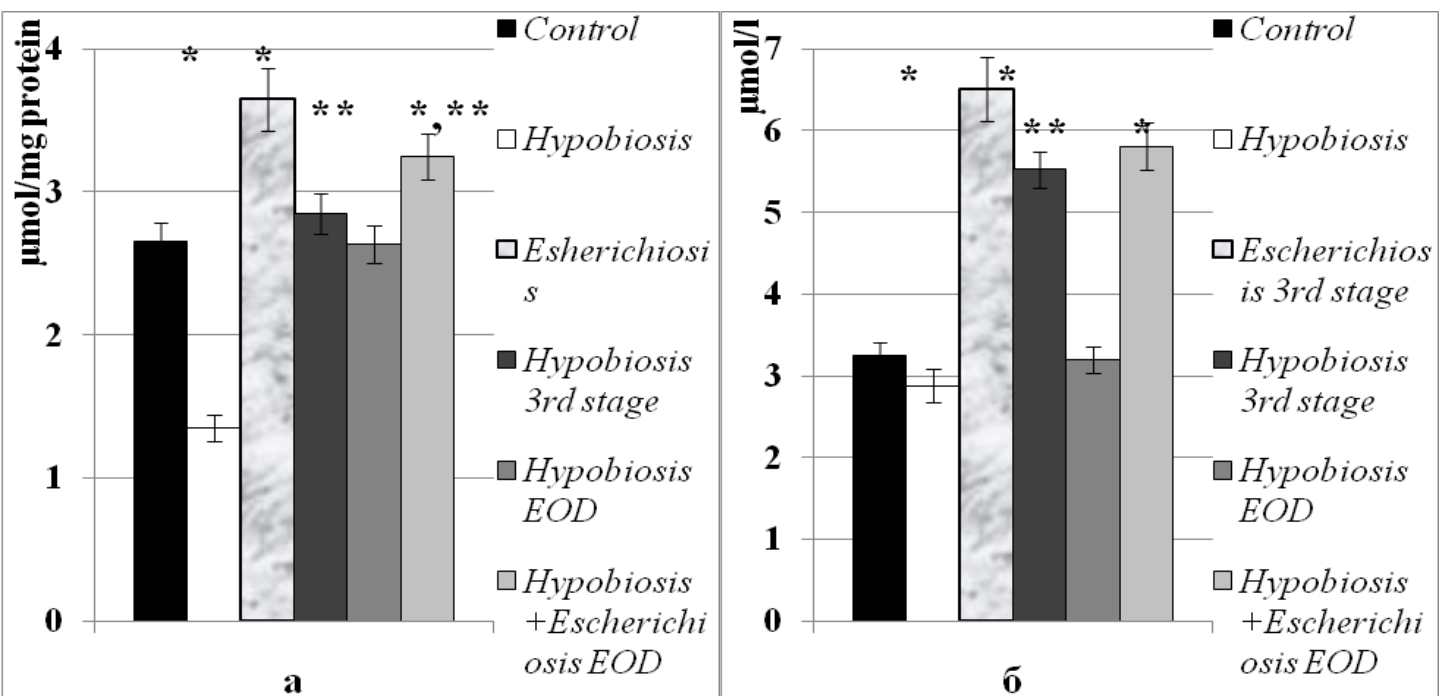

Fig. 3. The level of MDA in liver tissues of (a) and blood plasma (b) of rats that were introduced into the state of hypobiosis at the third stage of escherichiosis - the stage of total exhaustion of the body from the disease

The data obtained indicate a significant increase in the level of catabolic processes during the development of the disease, which is known to adversely affect the resistance mechanisms to the disease and may eventually lead to the death of the animal due to excessive damage to the oxidative nature and low organism opposition towards the damage elimination. Obviously, as a result of keeping the diseased animals without giving them appropriate treatment, $30 \%$ of animals are killed. Therefore, it is important to have various therapeutic measures that would adjust the biochemical parameters of the body and help it eliminate the effects of oxidative stress. It is possible to register the course of the processes of such a schedule by examining in the tissues the level of MDA as a reliable criterion for the presence/absence of oxidative stress and the body's prospects for recovery. That is why the use of hypobiosis as a therapeutic state in infectious diseases seems to be a promising area of further research.

However, putting the healthy animals into a state of hypobiosis, while each of the state thereof (hypoxia, hypother- mia, hypercapnia) is definitely a stress-provoking factor, is accompanied by the lack of activating the MDA formation in the blood and in liver tissues (Fig. 1, 2, 3). Furthermore, the MDA level in liver tissues decreases almost twice as compared to the control values (Fig. 1a, 2a, 3a). Thus, the animals remain viable and the stress level in their tissues is reduced significantly. Alternatively, a sharp decrease in stress, i.e. MDA levels, is in fact a prerequisite for the organism's survival and can be used as a criterion for predicting viability. These data are consistent with those of other researchers who did not show signs of oxidative stress in the state of artificial hypobiosis in animals, and suggest that there is a switch in the role of ROS from stress to a signaling one and/or deactivation of ROS due to the effect of carbon dioxide on them [7].

Therefore, the use of artificial hypobiosis in healthy animals is in fact the application of the "conservation" mode of their vital functions and making it possible for the researchers to carry out surgical interventions without additional anesthesia and with minimal risk of blood loss. 
However, in our experiment, we introduced hypobiosis in the diseased animals. This undoubtedly imposes a mark on the laws of biochemical transformations that will take place when two factors go beyond the standard state of the organism.

We found that the levels of MDA that were registered after the application of artificial hypobiosis for the diseased animals were different from those of the diseased animals with which such treatment was not performed, and those of animals in the state of hypobiosis. The values of the recorded changes depended at what stage of disease development the body bad been in before hypobiosis was applied to it. However, in all cases, there was a significant decrease in MDA content as compared to the values of animals with escherichiosis at the corresponding stage (Figures 1, 2, 3).

Thus, for animals introduced into the state of hypobiosis at the stage of the initial symptoms of the disease, there was a decrease in MDA in liver tissues by $37 \%$, and blood plasma by $17 \%$ as compared to the parameters of the diseased animals at the first stage. The results obtained at this stage of the disease for liver tissue was $29 \%$ lower than that of the control animals. At the second and third stages of escherichiosis, the application of hypobiosis allows to reduce the MDA level in liver tissues as compared to the parameters of the diseased animals, and the obtained values are not statistically different from the control ones. For blood plasma, a decrease in MDA levels was observed for the diseased animals when they were put into the state of hypobiosis, although the obtained values of the decrease in this level for the diseased animals at the stage of the total exhaustion were the lowest, i.e., with the severity of the disease the difference between the level of MDAs in the diseased animals as well as the animals in relation to which hypobiosis was applied, tended to decrease.

Drawing on the data obtained, we can claim that the application of the state of hypobiosis, though not eliminating the problem of oxidative stress that occurs in the body of the diseased animal, still significantly reduces the level of MDA in these circumstances. Therefore, this fact can be regarded as a favorable one in terms of the future survival and recovery of the experimental subjects.

The data obtained are quite optimistic as a prognosis for the therapeutic use of hypobiosis. In fact, the set of factors that accompany the animals introduced into the experiment are themselves provocative of stressful situations. Thus, only the fact of the lack of adequate nutrition, which is characteristic of the animals with escherichiosis due to the reduced appetite and rejection of food at the later stages of the disease, induces LPO in homogenates of liver tissues of rats of different ages [16].

What are the possible reasons for MDA content decrease in application of the state of hypobiosis in the animals with escherichiosis as compared to the diseased animals that were not put into the state of hypobiosis? The very state of hypobiosis is accompanied by a decrease in the level of oxidation processes and, accordingly, low levels of MDA. As it is known, malonic dialdehyde is the result of transformations of polyunsaturated fatty acids, its further metabolic history can be expressed either in oxidation to carbon dioxide (which in fact should enhance the effect of hypercapnia), or this compound will have a destructive effect on the body through its reactivity with biomembrane lipides, conglomerating them and, consequently, disrupting transmembrane processes and conformational changes of membranes [16, 17]. Since the level of MDA in the process of hypobiosis decreases, it is obvious that new molecules are not formed, and a certain amount of the MDA molecules are transformed. To determine what role these transformations have for the body, you can remove it from the state of hypobiosis and estimate the level of MDA. Therefore, the next step in our research, which follows logically from the data obtained, is to evaluate the level of MDA in the diseased animals after their removal from the state of hypobiosis, and we conducted these investigations on day 1 after the animals' awakening.

It was established that the removal from the state of hypobiosis of animals that had been put into it at the stage of initial symptoms (stage I) and at the stage of progressive disease symptomatology (stage II), both in liver tissues, and in blood plasma is accompanied by the leveling of MDA to the magnitude of the control parameters. In this case, the excess $(14 \%)$ of the level of MDA in the plasma of animals of group II on the first day after leaving the state of hypobiosis is considered to be triggered by residual effects of escherichiosis, because the organism, which was in the phase of active development of the disease, actually recovers due to the state of hypobiosis, however should eliminate the effects of escherichiosis - enterotoxins circulating in the body, restore the water and electrolyte balance, the stable status of the oxidant-prooxidant system, etc.

However, for animals at the third stage of escherechiosis, the removal from hypobiosis is accompanied by an increase in MDA as compared to the animals at the third stage of hypopiosis, which were not awakened from artificial sleep. Obviously, the restoration of normal blood flow, which occurs when removing from hypobiosis and the re-saturation of tissues with oxygen, creates the conditions for various kinds of biochemical transformations coupled with dioxygen, which, in turn, is accompanied by the activation of MDA formation. In addition, it is likely that during this period in the liver the utilization of endotoxins is activated, and the excess products of the first phase of their transformation, accompanied by oxidative stress. Given the fact that the percentage of the diseased animals that survive after their introduction into the state of hypobiosis even at the stage of the total body exhaustion (stage III) exceeds the percentage of animals that survive in the absence of any measures $(90 \%$ vs. $70 \%$ ), in such case hypobiosis has a pronounced therapeutic effect.

At the molecular level, the application of hypobiosis in diseased animals can reduce the level of stress at all stages of the course of escherichiosis, both in liver tissues and in blood plasma. Obviously, the question of the survival of animals under these circumstances determine the individual characteristics of the body, while the state of hypobiosis in itself is a universal factor in reducing the stress molecule of MDA.

Conclusion. The results obtained indicate the prospect of the application of the state of hypobiosis for the treatment of escherichiosis at all stages of the disease. At the molecular level, the application of hypobiosis in diseased animals reduces the level of malondialdehyde in liver tissues and in blood plasma at all stages of the course of escherichiosis and after awakening of the animals.

It was determined that the level of malondialdehyde in the tissues of rats with escherichiosis gradually increases with the next stage of the disease (the initial stage of the disease, the stage of progressive symptoms and total exhaustion of 
the body), and the application of hypobiosis for healthy animals is accompanied by the pronounced reduction of this molecule concentration in healthy animals.

Changes in the concentration of malondialdehyde at the initial stage of the disease are much more pronounced in the blood plasma than in the liver tissues of the diseased animals. Therefore, it is specifically in the blood that the symptoms of oxidative stress in the state of escherichiosis can be recorded first.

\section{ЛІТЕРАТУРА}

1. Вихованець В.І. Показники енергетичного обміну в організмі тварин за умов штучного гіпобіозу. Автореферат дисертації на здобуття наукового ступеня кандидата біологічних наук 03.00.04 - біохімія. - Київ, 2005. 23 с.

2. Тимофеев Н.Н. Искусственный гипобиоз. Монография. Под редакцией Гоголиной Е.А. М.:Медицина. 1983. 192 с.

3. Andjus, R.K., Smith, A.U. Reanimation of adul trats from body temperature between 0 and $2{ }^{\circ} \mathrm{C} / / \mathrm{J}$ Physiol, 1955. Vol. 128. P. 446-472.

4. Andjus, R.K., Smith, A.U. Revivalof hypothermic rats after arrestof circulation and respiration// J Physiol, 1954. Vol. 123. P. 66-67.

5. Уманська А.О., Мельничук Д.О., Калачнюк Л.Г. Коронарографічне та магнітно-резонансне дослідження міокарда щурів за штучного гіпобіозу// Science Rise. Biological science. 2018. 3. C. $44-47$.

6. Уманська А.О., Мельничук Д.О., Калачнюк Л.Г. Зміни макро- і мікроелементного складу серця щурів за штучного гіпобіозу // Science Rise. Biological Science». - 2018. 1(10). C. $45-47$.

7. Мельничук Д.О., Мельничук С.Д. Гіпобіоз тварин - молекулярні механізми та практичне значення для сільського господарства і медицини: монографія. - К.: НАУ, 2007. - 220 с.

8. Ольховська О.М. Особливості клінічного перебігу і шляхи удосконалення лікування кишкових інфекцій у дітей на сучасному етапі // Annals of Mechnikov Institute. 2011. 4. С. 258-261.

9. Цвіліховський B.I., Текдемір I.О., Махендірараса Л.П. Стан гіпобіозу при ешерихіозі: часові рамки виживаності тварин i успішності застосування методу за ранньої та пізньої діагностики хвороби // Вісник проблем біології і медицини, 2019. Вип. 4, 2(154). С. 62-67.

10. Тарасов Н.І., Тепляков А.Т., Малаховіч Є.В. Стан перекисного окислення ліпідів, антиоксидантного захисту крові у хворих на інфаркт міокарда, обтяженим недостатністю кровообігу // Тер. архів. 2002. 12. С. $12-15$.

11. Резяпкин В.И., Слышенков В.С., Заводник И.Б., Бурдь В.Н., Сушко Л.И., Караедова Л.М., Романчук Е.И. Лабораторный практикум по биохимии и биофизике. - Гродненский государственный університет имени Янки Купалы. Гродо. ГрГУ, $2009.175 \mathrm{c}$.

12. Мельничук С.Д., Вихованець В.І. Вплив умов штучного гіпобіозу на енергетичний обмін у щурів, Український біохімічний журнал. 2005; 77 (3). 131-135.

13. ATCC Escherichia coli (Migula) Castellani and Chalmers (ATCC® 25922 ${ }^{\mathrm{TM}}$ ) Strain Designations: FDA strain Seattle 1946 [DSM 1103, NCIB 12210] /TypeStrain: no/ Biosafety Level:1 Availlable https://www.lgcstandardsatcc.org/products/all/25922.aspx?geo_country=ru

14. Владимиров Ю.А., Арчаков А.И. Перекисное окисление липидов. М.: Наука, 1972. - 252 с.

15. Усачова О.В., Пахольчук Т.М., Сіліна Є.А., Конакова О.В., Рябоконь Ю.Ю., Корогод С.М. Гострі кишкові інфекції у дітей (сучасні погляди на етіологію, патогенез, діагностику та лікування). Запоріжжя, 2014. 113 с.

16. Кричковская Л.В., Никитченко Ю.В., Дзюба В.Н. Химия и биохимия антиоксидантной системы организма при старении: учеб. пособие для вузов. Харьков. НТУ "ХПИ", 2012. $153 \mathrm{c}$.

17. Меньщикова Е.Б., Ланкин В.З., Зенков Н.К., Бондарь И.А., Круговых Н.Ф., Труфакин В.А. Окислительный стресс. Прооксиданты и антиоксиданты Москва: Слово, 2006. 556 с.

\section{REFERENCES}

1. Vikhovanetc, V.I. Indicators of energy metabolism in over weight animals by artificial hypobiosis. Abstract of dissertations for the degree of candidateof biological sciences 03.00.04 biochemistry. - Kyiv, 2005. 23 p.

2. Timofeev, N.N. Artificial hypobiosis. Monograph. Edited by Gogolina EA M.: Medicine. 1983. 192 p.

5. Umanskaya,A.O., Melnychuk,D.O., Kalachniuk, L.G. Coronary angiography and magnetic resonance imaging of rats with artificial hypobiosis // Science. Rise. Biological science. 2018. 3. P. 44-47.

6. Umanskaya,A.O., Melnychuk,D.O., Kalachniuk,L.G. Changes in macro- and micronutrient composition of the heart of rats in artificial hypobiosis // ScienceRise. Biological Science. 2018. 1 (10). P. 45-47.

7. Melnychuk D.O., Melnychuk S.D. Animal hypobiosis molecular mechanisms and practical implications for agriculture and medicine: monograph. - K .: NAU, 2007. - 220 p.

8. Olkhovska, O.N. Some peculiarities of clinical pictures and ways of improvement of treatment of intestinal infections at children today // Annals of Mechnikov Institute. 2011. 4. C. 258-261.

9. Tsvilikhovskyi V., Tekdemir I., Makhendirarasa L. State of hypobiosis during E.coli infection: a time frame work of animal survival and success of method application in conditions of early and later diagnosis of diseases // Visnyk problem biolohii i medytsyny, 2019. Is. 4, 2 (154). P. 62-67.

10. Tarasov, N.I., Teplyakov, A.T., Malakhovich, Ye.V. State of lipid peroxidation, antioxidant blood in survivors of myocardial infarction, burdened with circulatory in sufficiency // Ter. arkhiv. 2002. 12. P. 12-15.

11. Rezyapkin, V.I., Slyshenkov, V.S., Zavodnik, I.B., Burd, V.N., Sushko, L.I., Karaedova, L.M., Romanchuk, E.I. Laboratory Workshop on Biochemistry and Biophysics. Grodnenskiy gosudarstvennyi universitet imeni Yanki Kupaly. Grodo. GrGU, 2009. 175 p.

12. Melnichuk, S.D., Vykhovanets, V.I. The Influence of the Conditions of the Artificial Hypobiosis on the Energy Exchange in Rats // Ukrainian Biochemical Journal. 2005. Is. 77 (3). P. 131-135.

14. Vladimirov, Yu.A., Archakov, A.I. Lipidperoxidation. M.: Nauka, 1972. - 252 p.

15. Usachova, O.V., Pakholchuk, T.M., Silina, Ye.A., Konakova, O.V., Ryabokon, Yu.Yu., Korohod, S.M. Acute intestinal infections in children (current views on etiology, pathogenesis, diagnosis and treatment). Zaporizhzhya, 2014. 113 p.

16. Krichkovskaya, L.V., Nikitchenko, Yu.V., Dzyuba, V.N. Chemistry and biochemistry of the antioxidant system of the body during aging: textbook. Manual for universities. Kharkov. NTU "KhPI", 2012. 153 p.

17. Menshchikova, E.B., Lankin, V.Z., Zenkov, N.K., Bondar, I.A., Krugovykh, N.F., Trufakin, V.A. Oxidative stress. Prooxidants and antioxidants. Moskva: Slovo, 2006. 556 p. 